\title{
Consumer Lifestyle Matters: Evidence from Gray Markets in China
}

\author{
Weining Liu ${ }^{1}$, Lan-Yun Chang ${ }^{2}$, Jing-Ru Lin ${ }^{1}$ \\ ${ }^{1}$ Graduate Institute of Human Resource and Knowledge Management National Kaohsiung Normal University, Kaohsiung, Taiwan; \\ ${ }^{2}$ Department of Creative Product Design, Far East University, Tainan, Taiwan. \\ Email: t3353@nknucc.nknu.edu.tw, kookiness2399@gmail.com
}

Received March $9^{\text {th }}, 2012$; revised April 10 ${ }^{\text {th }}, 2012$; accepted April 20 $0^{\text {th }}, 2012$

\begin{abstract}
Consumers are at the central point of marketing. However, while existential research is devoted to understanding gray market, little attention is given to the consumer's view of gray market. This study attempts to take the perspective of consumers to address the gray market issue. Lifestyles of the target customers of trademark holders are proposed for trademark holders to retain existing customers while simultaneously attracting new customers from the gray market. We perform Cluster analysis to identify different customer groups by using "lifestyle" as a market segmentation variable. ANOVA, Scheffe test and regression analyses are then employed to test the proposed hypotheses. Analytical results reveal that the different customer groups exhibit particular lifestyle features, different perceptions of gray product quality as well as different purchase intentions.
\end{abstract}

Keywords: Consumer Lifestyle; Product Quality Perception; Purchase Intention; Gray Market; Trademark Holders

\section{Introduction}

Gray market products are genuine branded goods sold at lower prices, but without the same intangible added value as their equivalent local authorized products. Specifically, gray market products can lag local authorized products in terms of service quality, warranty terms, and safety features [1]. However, with the rapid growth of electronic commerce, consumers are strongly aware of the availability of gray products and are accustomed to purchasing them. Although trademark holders stress that the prices charged by authorized distributors include a significant degree of skilled customer service that is provided only through an authorized agent, vendors of gray market products compete by offering their own after-sales services, resulting in fierce competition [2]. To compete with gray market products trademark holders employ market segmentation to distinguish their target customers from gray product dealers [3]. Scholars tried to provide feasible solutions according to the legal perspective. However, inappropriate enforcement of gray market laws may erode common market growth [4-9]. Gray market products cover all aspects of the commercial spectrum, ranging from medical supplies to luxury items such as perfume, watches, electronic products, and so on [10]. In this study, we will focus on digital cameras in China. What is happening in China is a new illustration of the economies of scale. Millions of Chinese are finally making enough to buy the consumer goods like digital cameras. It's no coincidence that Chinese are bringing home more memories from trips. The World Tourism Organization says 20 million traveled abroad in 2003 and that this number should quintuple by 2020 . And digital camera sales have room to grow at a similar pace [11]. As price and service have been shown to be a major influence on customer satisfaction for digital camera [12], this study attempts to take an alternative view that is to address the gray market issue from a demand perspective, the perspective of the consumer. Consumers have long been at the center of marketing. Their perceptions of gray market products may be expected to influence their behavior; knowledge of the consumers is essential to trademark holders to learn which market offerings best sat them. The consumer behavior literature states that lifestyle, including attitude, behavior and psychological profile, is an important influence on consumer consumption patterns, and can indicate attitudinal differences between segments [13-16]. Therefore, by segmenting markets according to lifestyles of the target customers, trademark holders will increase the likelihood of the combating strategies for gray markets. Figure 1 illustrates the relationships modeled in this study.

\section{Gray Market in China}

Within two decades of introducing an open door policy, 


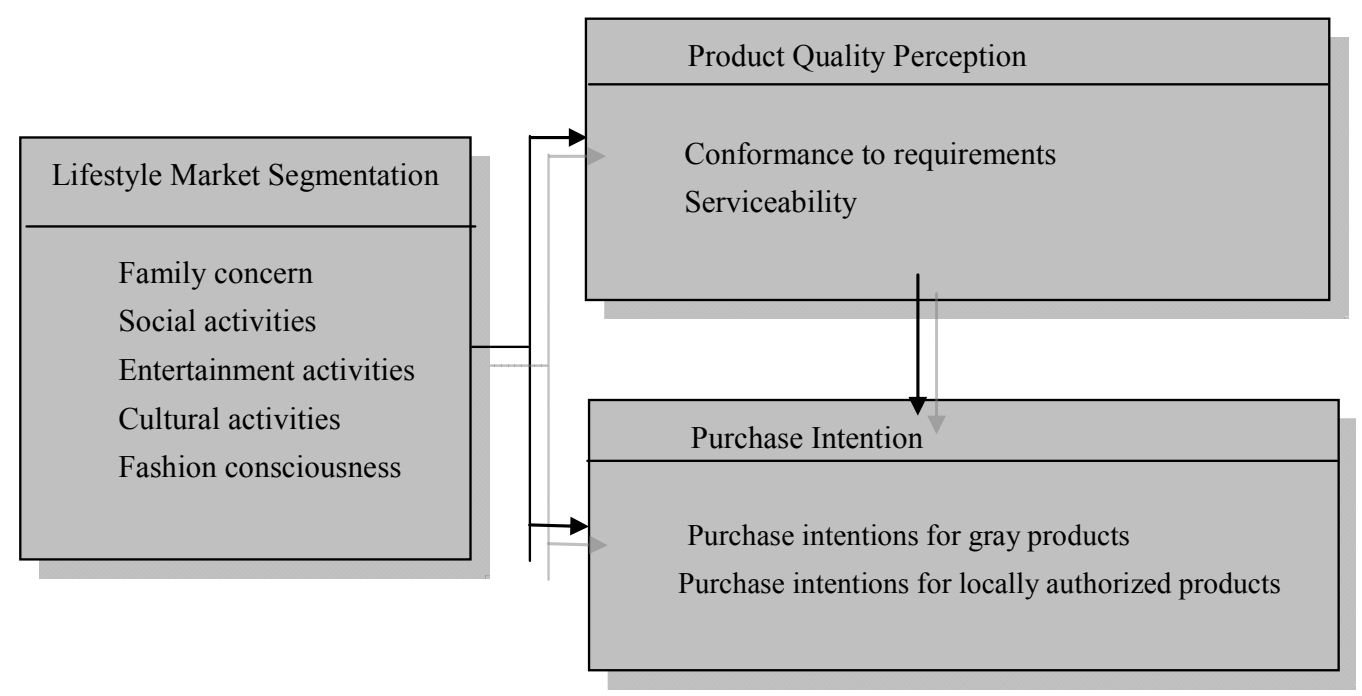

Figure 1. Research framework for lifestyle market segmentation, product quality perception and purchase intention.

China has moved from a state of isolation to being the second-largest recipient for FDI [17]. According to IMF's report, China's economic strength has become the third largest in the world. China's rising consumer class has attracted significant attention from both academic researchers and multinational marketers.

During the period of "Eight-five project" from 1985, the growing rate of consumption is far greater than the increasing rate of resident's income and keeps growing in the following years (Figure 2). On the other hand, people's deposit amount has reached RMB 3.9 trillions Yuan, which means the potential purchase power will be strong in the consumer markets (Figure 2). However, China went through 5000 years of feudal culture, thirty years of closed-suffering life of communism, and modernization through reform to use liberal policy to pursue substantial civilization. The transitions of culture, institution, and mental perception, have great impacts on Chinese people's values, consumer conceptions and even on consumer behavior [18]. Therefore, foreign traders who are planning to enter the Chinese market need to understand the intrinsic values of Chinese culture, consumer perception and behavior to make the foundations of their marketing strategies and plans.

As the development in rural and urban areas is different, consumer behavior is highly related to consumers' life-style [19]. China is not a single market, but many regional markets within the geographic boundaries of China, and that each region will have very different characteristics that will work for marketing strategies. "Shopping around." is the traditional shopping behavior of the Chinese. Because their average income is not high compared to world wide standard, it is also the reason why the Chinese shop with more caution, and apt to buy products which are more valuable than their price. However, price is no longer the only factor to the Chinese when shopping. They also care about the brand, functionality, quality, reliability and the after-sales service of the products. Accordingly, gray market products become attracttive to Chinese consumers. There are not any laws and regulations about the issues of gray markets in China. Most judicial interpretations and the views of scholars are inclined to allow parallel importation. Under this tendency, the authorized distributors will face great challenges. This special historical development of China market makes lifestyle segmentation an interesting issue for international brands who will expand their China market.

\subsection{Gray Market and Lifestyle Segmentation}

Previous studies demonstrated that trademark holders can develop effective marketing strategies for dealing with gray market if they can identify potential gray-market customers and forecast the preferences of various market segments $[3,20]$. The philosophy to keep any business alive is to understand customers' wants and needs [21, 22]. Research shows that advanced understanding of customers is one of the most important requirements of successful marketing strategies [23,24]. Expect for well understanding customers, the ability to categorize customers into quantifiable segments is also necessary. The consumer behavior literature states that lifestyle, including attitude, behavior and psychological profile, is an important influence on consumer consumption patterns, and can indicate attitudinal differences between segments. Lifestyle is thus deemed the main basis of segmentation [14-16]. "Lifestyle segmentation" has been a useful tool for marketing management decision making [25]. In marketing, "lifestyle segmentation" describes the lifelike portrait of the consumer and classified potential consumers into segments with specific and identifiable lifestyle patterns [26]. The life-style is closely associated 


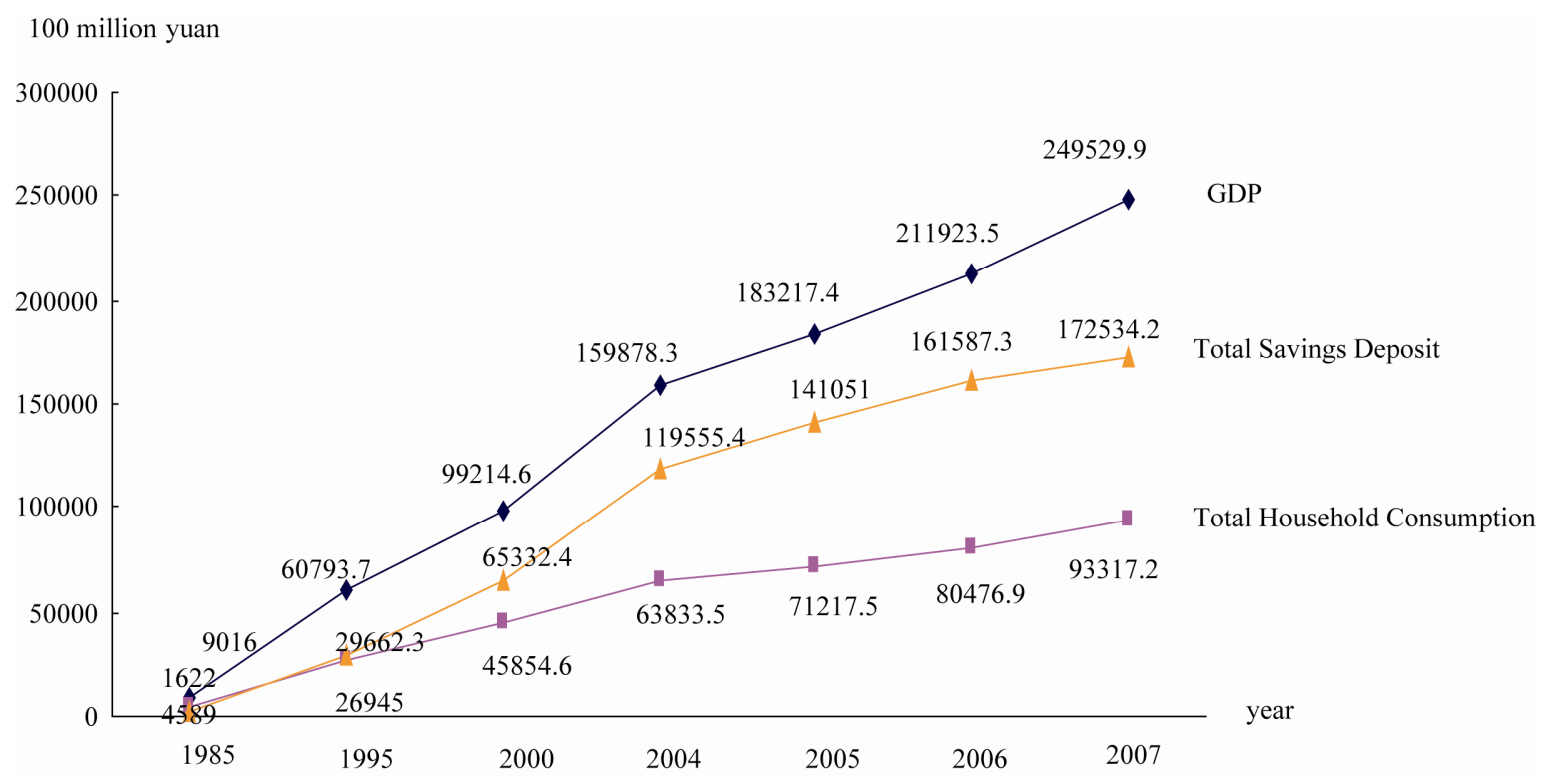

Figure 2. Basic statistics on people's living conditions in China.

with the economic level at which people live and how they spend their money [27]. This study applies the lifestyle segmentation approach to identify the characteristics of consumer groups that typically favor gray products and locally authorized goods. Then it provides trademark holders with differential strategies based on consumer perceptions of gray product quality and their corresponding purchase intentions.

\subsection{Lifestyle Segmentation and Product Quality Perception}

Quality is defined as product outcome or performance. Since quality indicates degree of goodness, it is frequently employed in product selection decisions [28]. Crosby et al. [29] indicated that quality is a key determinant of customer satisfaction, and consumer perceptions of product quality provide a basis for forecasting consumer behavior [30]. Orth et al. [31] employed lifestyle segmentation analysis to beer brand promotion, and found product quality to be an important value sought by customers. Since quality expectations are related to continued customer patronage, Thompson and Kaminski [32] employed lifestyle to segment health care consumers according to their expectations of service quality. Lifestyle segmentation can help marketers provide the satisfactory service quality demanded by target customers.

Champion [33] proposed that trademark holders should pay attention to the gray market segments constituted by gray product consumers, deal with them, and design different marketing programs for them [3]. Since most consumers are concerned with quality when discussing gray market products [34] and since consumer groups have specific lifestyle characteristics, brand preferences and choices [26,32], this study presents the following hypothesis to help trademark holders develop suitable strategies for competing with their gray market rivals.

H1: Different lifestyle segments have different perceptions of gray product quality.

\subsection{Lifestyle Segmentation and Purchase Intentions}

Analyzing customer purchase intentions enables the forecasting of purchase behavior [35,36]. Accordingly, purchase intention indicates purchase likelihood, and is thus an important variable in analyzing customer behavior. Generally, a higher purchase intention is associated with a higher likelihood of purchase-making [37,38]. Previous studies have frequently adopted the concept of purchase intention to examine the different purchasing attitudes of consumers [34,35]. Martin and Bush [39] applied purchase intention to analyze the purchasing patterns of adolescent consumers, and demonstrated that purchase intention enables marketing managers to effectively differentiate consumers who are likely and unlikely to purchase a product. Armed with this knowledge, marketers can then develop incentives to actively stimulate the purchase intentions of prospective buyers. Furthermore, marketers can target individuals with only a weak desire to buy the product or with no desire using appropriate marketing strategies to stimulate their purchase intentions $[36,40]$.

Previous studies have reported that consumer lifestyle positively influences purchase intention [26,41]. Thus, using lifestyle segmentation to classify distinct customer groups, and then identifying the purchase intentions of individual customer segments, provides trademark hold- 
ers with a valuable knowledge base for formulating appropriate marketing strategies. This study thus hypothesizes that:

H2: Different lifestyle segments have different purchase intention of gray product.

\subsection{Product Quality Perception and Purchase Intention}

Numerous studies confer that quality is markedly associated with customer purchase intentions [42]. Earlier, Shawyer et al. [43] concluded that the likelihood of a consumer making a purchase decision increases with consumer perception of product quality. Furthermore, perceived product quality affects consumer attitudes, faithfulness and repeat purchase behavior. Studies have also shown that consumer perceptions of a product or service as being of high quality directly or indirectly increase consumer purchase intentions [37]. This study examines the relationship between consumer perceptions of gray product quality and purchase intentions. Specifically, this study hypothesizes that:

H3: Consumers' perceptions of gray product quality positively impact their purchase intentions.

\section{Methodology}

The present analysis is based on empirical data obtained via a self-administered questionnaire. The questionnaire was developed in English and then translated into Chinese. The comparability between the two versions of the questionnaire was confirmed through back translation. The questionnaire comprised four sections, covering lifestyle, product quality perceptions, purchase intentions and demographic variables, respectively. Besides the points related to the demographic variables, the measurement items were all expressed using five-point Likert scales ranging from 1 (indicating "strongly disagree") to 5 (indicating "strongly agree").

To validate the construction of the survey measure, the questionnaire was pre-tested by distributing 40 copies among commercial centers in Hai-Dian, Beijing, where gray products are selling in many stores. Respondents were asked to give suggestions regarding the format, wording, and measurement problems of the questionnaire. From the 32 copies returned, the Cronbach's $\alpha$ for lifestyle was 0.92 , while those for product quality perceptions and purchase intentions were 0.89 and 0.91 , respectively. The results show that the measurement problems for each variable in the pre-test have good reliability, demonstrating the relevance of the questionnaire. Since the questionnaire contained no inappropriate content, only its wording was revised here.

The formal questionnaires were distributed among commercial centers in Beijing, Tianjin and Shanghai in
China to respondents randomly selected on the spot. After ascertaining that the respondents fully understood the meanings of gray market and authorized market, and had purchased gray and locally authorized products, the respondents were asked to complete the questionnaire. A total of 1000 copies of the questionnaire were distributed, of which 798 were returned. Eliminating incomplete questionnaires or those with uniform answers, a total of 728 valid questionnaires remained, representing a response rate of around $72.8 \%$. Of the valid ones, $57 \%$ were completed by males and $43 \%$ by females. Regarding respondent age distribution, respondents aged below 20 years old accounted for $21 \%$; those aged between 21 and 30,35\%; those between 31 and 40, 26\%; those between 41 and 50, 11\%, and those over 51, 7\%. Regarding geographical distribution, 39\% were from Beijing, 27\% from Tianjin, and 34\% from Shanghai.

\section{Measures}

Lifestyle: Respondent lifestyles were assessed using a 24-item scale adapted from [26] and expressed through conventional AIO statements. The collected lifestyle data were analyzed using factor analysis based on principal component extraction and varimax rotation. Five solution factors were obtained, named "family concern", "social activities", "entertainment activities", "cultural activities" and "fashion consciousness", respectively. The Cronbach's $\alpha$ value of all dimensions was found to exceed 0.7 , a level judged acceptable for current research purposes.

Product quality perception: Taking the classifications of product quality proposed by Crosby et al. [29] and Teas and Agarwal [30], five-point Likert scales were developed to measure respondent perceptions of gray product quality. Factor analysis yield two dimensions, "conformance to requirements" and "serviceability", respectively. The Cronbach's $\alpha$ value of both dimensions was found to exceed 0.7 , and thus both of the dimensions were considered reliable indicators of respondent product quality perception.

Purchase intention: Taking the items proposed by Li et al. [35], Goode and Harris [44], and Martin and Bush [39] as a reference, five-point Likert scales were established to assess respondent purchase intentions regarding gray market goods. Factor analysis yielded two dimensions, "purchase intention for gray products" and "purchase intention for locally authorized products", respectively. The Cronbach's $\alpha$ of both dimensions both exceeded 0.7 , and thus both of the dimensions were considered reliable indicators of respondent purchase intentions.

\section{Results and Analysis}

The analysis of respondent data was commenced by performing a factor analysis to identify the dimensions life- 
style, product quality perception and purchase intention. Cluster analysis was then conducted based on the five lifestyle factors identified by the factor analysis to assign the 728 respondents to appropriate cluster groups. Subsequently, multiple discriminant analysis was conducted to determine the effectiveness of the result of cluster analysis in differentiating consumer lifestyle groups and establishing their relative importance. One-way ANOVA and Scheffe tests were performed to test statistically significant differences among the different cluster groups in terms of their product quality perceptions and purchase intentions. Finally, regression analysis was conducted to examine the correlation between consumer product quality perceptions and their purchase intentions.

\subsection{Cluster Analysis}

Cluster analysis is frequently applied in market segmentation research [16]. The two-stage cluster analysis of the hierarchical and non-hierarchical (K-Means) method is used in this study to identify target customers of gray and authorized markets. The hierarchical method is applied to determine whether the number of clusters is appropriate via analysis of the large difference among clustering coefficients in the agglomeration schedule, demonstrating that three-cluster solutions are chosen as the appropriate number of clusters (Table 1). The K-Means procedure is then used, based on the five lifestyle factors extracted via factor analysis. The results show that 178 cases were found in Cluster 1 (24.5\%), 264 cases in Cluster $2(36.3 \%)$, and 286 cases in Cluster 3 (39.2\%) (Table 2).

\subsection{Discrimanant Analysis}

As various previous researchers have speculated on thereliability and validity of results obtained via cluster analysis [16], discriminant analysis was performed to validate the current clustering results. Two canonical correlation functions were generated, i.e. $\mathrm{F} 1: \mathrm{X}_{(10)}^{2}=$ 1059.498, Wilks' Lambda $=0.2310, \mathrm{P}<0.001$; and $\mathrm{F} 2$ : $\mathrm{X}_{(4)}^{2}=484.739$, Wilks' Lambda $=0.5115, \mathrm{P}<0.001$. Both correlation functions were statistically significant, confirming their validity for cluster classification. Func-

Table 1. Clustering coefficients of hierarchical cluster analysis.

\begin{tabular}{|c|c|c|c|c|c|c|c|}
\hline \multirow{2}{*}{ Stage } & \multicolumn{2}{|c|}{$\begin{array}{c}\text { Clusters } \\
\text { Combined }\end{array}$} & \multirow[t]{2}{*}{ Clustering } & \multicolumn{2}{|c|}{$\begin{array}{c}\text { Stage Cluster } \\
\text { Appears }\end{array}$} & \multicolumn{2}{|c|}{ Next Cluster } \\
\hline & \multicolumn{6}{|c|}{ Cluster 1 Cluster 2 Coefficients Cluster 1 Cluster 2 Stage Number } & \\
\hline 724 & 1 & 89 & 21.829017 & 723 & 715 & 726 & 4 \\
\hline 725 & 263 & 267 & 22.255836 & 720 & 714 & 726 & 3 \\
\hline 726 & 1 & 263 & 25.598206 & 724 & 725 & 727 & 2 \\
\hline 727 & 1 & 269 & 27.010431 & 726 & 698 & 0 & 1 \\
\hline
\end{tabular}

tion 1 can effectively distinguish clusters 1 and 3 , while function 2 can distinguish cluster 2 and others (Figure 3). The correct cluster classification rate (i.e. the overall hit ratio) was $95.47 \%$ (Table 3), and hence it was deduced that the cluster analysis results were sufficiently reliable for the current purpose.

\subsection{Characteristics of Clusters}

The mean and Scheffe test results for cluster groups and lifestyle factors (Table 4) show that Cluster 1 exhibited "family concern" and "cultural activities" lifestyle characteristics, and thus is a group that enjoys housekeeping and is more family oriented than any other cluster. Meanwhile, the lifestyle features of Cluster 2 are related primarily to the "social activities" and "cultural activities" factors; so they like going to public places and participating in outdoor activities better than consumers in other clusters. Finally, the lifestyle features of cluster 3 are related primarily to the "fashion consciousness" and "entertainment activities" factors; and the cluster is a group who care more about being fashionable, and are more interested in new and unique products, more enthusiastic about traveling, and more interested in people and friends than any other cluster (Table 4).

\subsection{Test of Hypothesis}

The ANOVA analysis results for lifestyle segmentation and product quality perception (Table 5) demonstrate that all lifestyle segments perceive gray product quality differently. The results indicate that three statistically significant clusters are in relation to the "conformance to requirements" and "serviceability" factors of gray product

Table 2. Cluster analysis results based on five lifestyle factors.

\begin{tabular}{lllll}
\hline Segmentation & Cluster 1 & Cluster 2 & Cluster 3 & Total \\
\hline Number of samples & 178 & 264 & 286 & 728 \\
Percentage & $24.5 \%$ & $36.3 \%$ & $39.2 \%$ & $100 \%$ \\
\hline
\end{tabular}

Table 3. Discriminant analysis of clustering results shown in Table 4.

\begin{tabular}{ccccc}
\hline Actual Group & \multicolumn{3}{c}{ Predicted Group } & Total \\
\hline \multicolumn{1}{c}{1} & 2 & 3 & \\
Cluster 1 & $\mathbf{1 6 2 ( 9 1 . 0 \% )}$ & $8(4.5 \%)$ & $8(4.5 \%)$ & 178 \\
Cluster 2 & $7(2.7 \%)$ & $\mathbf{2 5 5}(\mathbf{9 6 . 6 \% )}$ & $2(0.8 \%)$ & 264 \\
Cluster 3 & $2(0.7 \%)$ & $6(2.1 \%)$ & $\mathbf{2 7 8 ( 9 7 . 2 \% )}$ & 286 \\
$\begin{array}{l}\text { Percent of "grouped" cases correctly classified } \\
=(162+255+278) / 728=95.47 \% \text { (Hit Ratio) }\end{array}$ & \\
\hline
\end{tabular}

The correct rate of percentage is in parenthesis. 


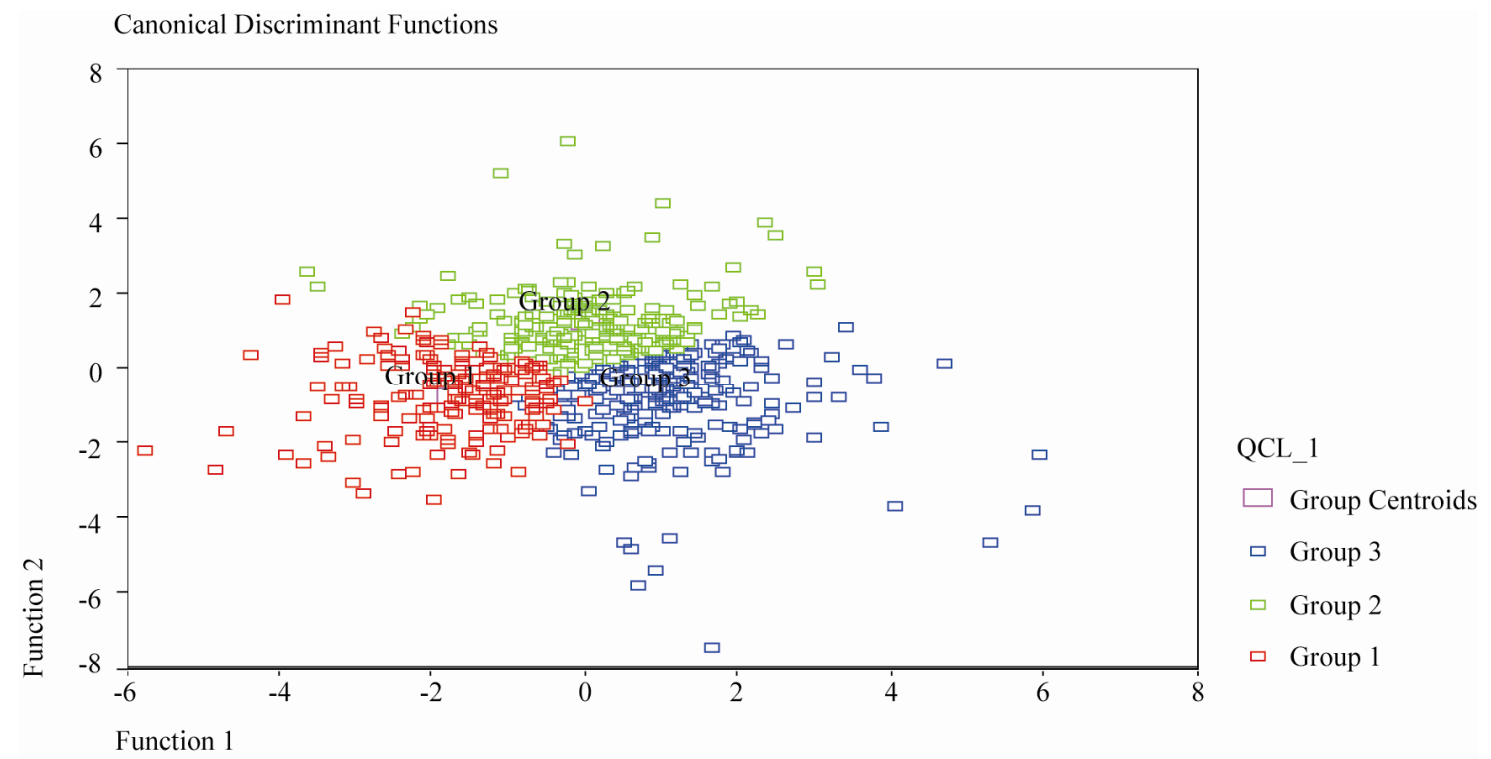

Figure 3. Clustering results. Function $1=-0.56274 Y 1^{*}+0.46502 Y 2+0.29359 Y 3-0.59282 Y 4^{*}+0.83241 Y 5^{*} ;$ Function $2=$ 0.00437 Y $1+0.88469 Y^{*}-0.277913^{*}+0.46792 Y 4-0.31175 Y 5$; .denotes largest absolute correlation between each variable and each discriminant function.

Table 4. Mean and Scheffe test results for cluster groups and lifestyle factors.

\begin{tabular}{|c|c|c|c|c|c|}
\hline Cluster and Naming & Family & Social & Entertainment & Cultural & Fashion \\
\hline & Concern & Activities & Activities & Activities & Consciousness \\
\hline Cluster 1 & 0.47 & -0.95 & -0.13 & 0.33 & -0.64 \\
\hline Cluster 2 & -0.001 & 0.81 & -0.19 & 0.33 & -0.23 \\
\hline Cluster 3 & -0.29 & -0.15 & 0.25 & -0.51 & 0.61 \\
\hline F value & $34.018^{* * *}$ & $321.89^{* * *}$ & $16.07^{* * *}$ & $74.76^{* * *}$ & $132.30^{* * *}$ \\
\hline \multirow[t]{3}{*}{ Scheffe test } & $1>2$ & $1<2$ & $1<3$ & $1>3$ & $1<2$ \\
\hline & $1>3$ & $1<3$ & $2<3$ & $2>3$ & $1<3$ \\
\hline & $2>3$ & $2>3$ & & & $2<3$ \\
\hline
\end{tabular}

\footnotetext{
${ }^{* * *} \mathrm{P}<0.001 ;{ }^{* *} \mathrm{P}<0.01 ;{ }^{*} \mathrm{P}<0.05$.
}

quality perception $(\mathrm{P}<0.001)$. Hypothesis $\mathrm{H1}$, namely that all lifestyle segments have different perceptions of gray product quality, thus is supported. Generally, the results listed in Table 5 support the following inferences: 1) members of cluster 1 have the lowest consent of gray product quality; 2) members of clusters 2 and 3 perceive gray product quality as conforming to requirements; 3 ) members of cluster 3 do not consent to the "serviceability" of gray product quality, and 4) members of cluster 2 exhibit the greatest consent to the serviceability of the three clusters.

The ANOVA analysis results for lifestyle segmentation and purchase intention (Table 6) indicate that all lifestyle segments have different purchase intentions regarding gray products. As shown, all three clusters are statistically significant $(\mathrm{P}<0.001)$ for both "purchase intention for gray products" and the "purchase intention for locally authorized products". Therefore, hypothesis $\mathrm{H} 2$, i.e. that all lifestyle segments of customers have different purchase intentions of gray product, is supported. The ANOVA results support the following specific inferences: 1) members of cluster 1 exhibit no specific preferences for either locally authorized or gray products, renamed "Neutral"; 2) members of cluster 2 show a preference for locally authorized products, renamed "Trademark Lover"; and 3) members of cluster 3 prefer gray products, renamed "Gray Product Lover".

Finally, the regression analysis results indicate that consumer perceptions of gray product quality statistically significantly influence their purchase intentions $(\mathrm{P}<$ 0.001) (Table 7). Therefore, hypothesis H3, i.e. that consumer perceptions of gray product quality positively 
Table 5. ANOVA analysis results for cluster member perceptions of gray product quality.

\begin{tabular}{ccc}
\hline Cluster & \multicolumn{2}{c}{ Product Quality Perception } \\
\hline Cluster 1 & Conformance to requirements & Serviceability \\
Cluster 2 & -0.31 & -0.26 \\
Cluster 3 & 0.07 & 0.18 \\
F value & 0.12 & -0.006 \\
P value & 11.903 & 10.399 \\
Scheffe Test & $0.000^{* * *}$ & $0.000^{* * *}$ \\
${ }^{* * * *} \mathrm{P}<0.001 ;{ }^{* *} \mathrm{P}<0.01 ;{ }^{*} \mathrm{P}<0.05$. & $1<2,1<3,2>3$ \\
\hline
\end{tabular}

Table 6. ANOVA analysis results for cluster member purchase intentions.

\begin{tabular}{lcc}
\hline \multicolumn{1}{c}{ Cluster } & \multicolumn{2}{c}{ Purchase Intention } \\
\hline & Gray Products & Locally Authorized Products \\
Neutral (Cluster 1) & -0.26 & -0.33 \\
$\begin{array}{l}\text { Trademark Lover } \\
\text { (Cluster 2) }\end{array}$ & 0.06 & $\mathbf{0 . 2 1}$ \\
$\begin{array}{l}\text { Gray Product Lover } \\
\text { (Cluster 3) }\end{array}$ & $\mathbf{0 . 1 1}$ & 0.01 \\
F value & 8.363 & 16.20 \\
P value & $0.000^{* * *}$ & $0.000^{* * *}$ \\
Scheffe Test & $1<2,1<3$ & $1<2,1<3$ \\
${ }^{* * *} \mathrm{P}<0.001 ;{ }^{* *} \mathrm{P}<0.01 ;{ }^{*} \mathrm{P}<0.05$. &
\end{tabular}

impact their purchase intentions, is supported. Furthermore, the results show that both the "conformance to requirements" and "serviceability" dimensions of product quality perception significantly affect consumer purchase intentions.

\section{Discussion}

This study provides trademark holders with insight into the lifestyles of their existing and potential customers. Generally, five lifestyle segmentation factors have been identified, namely "family concern", "social activities", "entertainment activities", "cultural activities" and "fashion consciousness". Furthermore, three distinct customer groups have been identified, i.e. "Neutral", "Trademark Lover" and "Gray Product Lover".

The conclusions of this study demonstrate that different lifestyle segments of customers have different perceptions of gray product quality and different purchase intention. Members of the "Trademark Lover" group, who exhibit lifestyle characteristics by "social activities" and "cultural activities", prefer locally authorized goods, and they are mostly customers of trademark holders. Interestingly, although this group agrees that gray products
Table 7. Regression analysis results of product quality perception on purchase intention.

\begin{tabular}{|c|c|c|}
\hline \multirow{2}{*}{$\begin{array}{l}\text { Product Quality } \\
\text { Perception }\end{array}$} & \multicolumn{2}{|c|}{ Purchase Intention } \\
\hline & Gray Products & Locally Authorized Products \\
\hline $\begin{array}{l}\text { Conformance to } \\
\text { requirements }\end{array}$ & $0.276^{* * *}$ & $0.187^{* * *}$ \\
\hline Serviceability & $0.387^{* * *}$ & $0.203^{* * *}$ \\
\hline $\operatorname{Adrj}^{2}$ & 0.224 & 0.085 \\
\hline F value & 105.628 & 34.908 \\
\hline$P$ value & $0.000^{* * *}$ & $0.000^{* * *}$ \\
\hline
\end{tabular}

${ }^{* * *} \mathrm{P}<0.001 ;{ }^{* *} \mathrm{P}<0.01 ;{ }^{*} \mathrm{P}<0.05$

offer good after-sale service and conform to their requirements, they still favor locally authorized goods. This preference results from the fact that this group frequently visit public places, and enjoy literary, religious and cultural activities, i.e. they like to declare, intentionally or unintentionally, that their clothes or possessions are locally authorized purchases for the sake of face or vanity. As a strategy to retain these customers, trademark holders should consider offering various after-sale service portfolios tailored to their preferences, including discount coupons for future sales, VIP cards for special treatment, or gift coupons for various products. And after-sale service schemes may make customers feel that their business is valued and their repeat purchase intention is encouraged.

Conversely, customers of the "Gray Product Lover" cluster group prefer gray products to locally authorized ones. This group possesses "fashion consciousness" and "entertainment activities" lifestyle characteristics, regarding themselves as fashion leaders, and enjoying traveling and conversing with others. Consequently, they enjoy numerous opportunities to obtain and dispense information regarding gray products. Importantly, such consumers derive a strong sense of satisfaction from acquiring new and unique products. To deal with such consumers, trademark holders may apply a product differentiation strategy, i.e. offer different products tailored to individual markets so as to cater to local consumer wishes. Furthermore, as stated in the results of this study, gray product lover does not think that gray market can offer good after-sale service for what it sells. Trademark holders may stress that only by acquiring locally authorized products can consumers be guaranteed effective aftersales service backed by appropriate professional knowledge and skill. Trademark holders may also consider reducing the prices of locally authorized products to minimize the price advantage of their gray rivals. Restated, the development of appropriate promotion and market positioning strategies may be sufficient to per- 
suade consumers to alter their purchasing behavior to favor locally authorized products.

Finally, individuals in the "Neutral" cluster exhibit no special preferences for either gray market or locally authorized products. Such consumers comprise the group that possesses stronger "family concern" lifestyles characteristics than other groups. Such consumers have no strong preferences for either product type, and nor do they consent to the conformity of gray market product to perceived requirements and serviceability. Consequently, most members of this cluster are potential customers for trademark holders. Locally authorized agents thus should position their products as family oriented, stressing that their appeal to the whole family, to attract consumers in this cluster group to make purchases.

Our results have confirmed that consumer perceptions of gray product qualities positively impact purchase intentions. Consequently, it is reasonable to infer that consumer perceptions of gray product quality not only influence purchase intentions regarding gray products, but also determine purchase intentions regarding locally authorized products. The findings here indicate that a gray market may not necessarily adversely impact trademark holders. That is, provided consumers perceive the quality of locally authorized products to be superior to that of their gray market equivalents, they are likely to become loyal local authorized market customers. Thus trademark holders should strive to increase the perceived added value of their products sold through local authorized market and formulate differential strategies for each cluster to gain their competitive advantage.

\section{Conclusions}

The emergence of the gray market as a powerful competitor to trademark holders can be attributed partially to the blurry purchasing behavior of the customer base. Since it is difficult for trademark holders to accurately identify who are gray product purchasers, they face problems in developing effective strategies to deal with their gray market competitors. Trademark holders thus must identify their target customers and analyze their consumption behavior [3]. In this regard, the results presented here make a valuable contribution since they reveal that a market segmentation approach offers a means for trademark holders to gain a position that improves their odds of success.

The lifestyle segmentation results presented in this study have identified three customer groups, each with different lifestyle characteristics, product quality perceptions and purchase intentions. The analytical results provide trademark holders with a valuable source of information for developing effective strategies to retain existing customers and attract new ones. The gray market has been increasingly active in China since 1979, forcing trademark holders to respond by promoting their after-sales services. However, experience has shown that this strategy has low reliability [2]. Therefore, applying a market segmentation approach and developing product differentiation strategies should be considered by trademark holders to attract customers and build customer loyalty.

With $20 \%$ of global consumers in the world, China is an ideal market for trademark holders. Owing to the lack of enforcement of laws prohibiting the sale of gray products in China, trademark holders face a crucial problem of how to deal with such products. The findings and recommendations of this study have practical implications for trademark holders seeking to gain competitive advantage in China. However, since most respondents answering the questionnaire are Chinese consumers, and since human lifestyles may change according to the culture of one's native place, the results presented in this study may not apply elsewhere. Future researchers may examine consumer attitudes toward gray market goods in countries in which they are interested, and develop specific reference materials to benefit trademark holders.

\section{REFERENCES}

[1] J. B. Thomas and C. L. Okleshen, "The Underground Mall: An Investigation of Factors Influencing Gray Market Consumption," International Journal of Retail \& Distribution Management, Vol. 34, No. 2, 2006, pp. 106-120. doi:10.1108/09590550610649777

[2] China Review, "Why Do Chinese Like Gray Market Products?" 2008.

http://www.chinareviewnews.com/doc/1006/3/8/0/10063 8054. html? coluid $=59 \&$ kindid $=0 \&$ docid $=100638054 \& \mathrm{md}$ ate $=0507102031$

[3] B. C. Y. Lee, "Consumer Perceived Importance of Channel Authorization: A Post Hoc Segmentation Approach to Dealing with Gray Markets," Australasian Marketing Journal, Vol. 14, No. 1, 2006, pp. 10-23. doi:10.1016/S1441-3582(06)70050-7

[4] S. J. Alberts, "Trademarks and Gray Market Goods: Why U.S. Trademark Holders Should Be Held Strictly Liable for Defective Gray Market Imports," The George Washington Journal of International Law \& Economics, Vol. 25, No. 3, 1992, pp. 841-873.

[5] K. Antia, M. E. Bergen, S. Dutta and R. Fisher, "How Does Enforcement Deter Gray Market Incidence?" Journal of Marketing, Vol. 70, No. 1, 2006, pp. 92-106. doi:10.1509/jmkg.2006.70.1.92

[6] T. Z. Chang, "Parallel Importation in Taiwan: A View from a Newly Emerged," International Marketing Review, Vol. 10, No. 6, 1993, pp. 30-42. doi: $10.1108 / 02651339310051605$

[7] N. T. Gallini and A. Hollis, "A Contractual Approach to the Gray Market," International Review of Law and Economics, Vol. 19, No. 1, 1999, pp. 1-21. doi:10.1016/S0144-8188(98)00032-5 
[8] P. E. Chaudhry and M. G. Walsh, "Gray Marketing of Pharmaceuticals," Journal of HealthCare Marketing, Vol. 15, No. 3, 1995, pp. 18-22.

[9] M. Prince, "Seeing Red over International Gray Markets," Business Horizons, Vol. 43, No. 2, 2000, pp. 71-74. doi:10.1016/S0007-6813(00)88563-8

[10] P. S. Sloane, "Preventing the Unauthorized Importation of Altered Gray Market Goods: Practical Suggestions for US Trademark Owners," Intellectual Property and Technology Law Journal, Vol. 16, No. 6, 2004, pp. 12-16.

[11] R. Meredith, "Middle Kingdom, Middle Class," Forbes, Vol. 174, No. 10, 2004, pp. 188-192

[12] K. W. J. Jih, S. F. Lee and Y. C. Tsai, "Effects of Service Quality and Shared Value on Trust and Commitment: An Empirical Study of 3Cs Product Customers in Taiwan," International Journal of Business Studies, Vol. 15, No. 2, 2007, pp. 83-98.

[13] R. E. Goldsmith, L. Flynn, E. Goldsmith and C. E. Stacey, "Consumer Attitudes and Loyalty towards Private Brands," International Journal of Consumer Studies, Vol. 34, No. 3, 2010, pp. 339-348. doi:10.1111/j.1470-6431.2009.00863.x

[14] N. Scott and N. Parfitt, "Lifestyle Segmentation in Tourism and Leisure: Imposing Order or Finding It?" Journal of Quality Assurance in Hospitality \& Tourism, Vol. 5, No. 2-4, 2004, pp. 121-139. doi:10.1300/J162v05n02_07

[15] P. Vyncke, "Lifestyle Segmentation: From Attitudes, Interests and Opinions, to Values, Aesthetic Styles, Life Visions and Media Preferences," European Journal of Communication, Vol. 17, No. 4, 2002, pp. 445-463. doi:10.1177/02673231020170040301

[16] K. C. C. Yang, "A Comparison of Attitudes towards Internet Advertising among Lifestyle Segments in Taiwan," Journal of Marketing Communications, Vol. 10, No. 3, 2004, pp. 195-212. doi:10.1080/1352726042000181657

[17] J. Child and D. K. Tse, "China's Transition and Its Implications for International Business," Journal of International Business Studies, Vol. 32, No. 1, 2001, pp. 5-21. doi:10.1057/palgrave.jibs.8490935

[18] T. Sun, M. Horn and D. Merritt, "Values and Lifestyles of Individualists and Collectivists: A Study on Chinese, Japanese, British and US Consumers," Journal of Consumer Marketing, Vol. 21, No. 5, 2004, pp. 318-331. doi:10.1108/07363760410549140

[19] H. Dagevos, Y. He, X. Zhang, I. van der Lans and F. Zhai, "Relationships among Healthy Lifestyle Beliefs and Body Mass Index in Urban China," International Journal of Consumer Studies, Vol. 35, No. 1, 2011, pp. 10-16. doi:10.1111/j.1470-6431.2010.00926.x

[20] K. D. Antia, M. Bergen and S. Dutta, "Competing with Gray Markets," MIT Sloan Management Review, Vol. 46, No. 1, 2004, pp. 63-69.

[21] D. R. John, B. Loken, K. Kim and A. B. Monga, , "Brand Concept Maps: A Methodology for Identifying Brand Association Networks," Journal of Marketing Research, Vol. 43, No. 4, 2006, pp. 549-563. doi:10.1509/jmkr.43.4.549

[22] G. Zaltman, "Rethinking Market Research: Putting People Back in," Journal of Marketing Research, Vol. 34, No.

\section{4, 1997, pp. 424-437. doi:10.2307/3151962}

[23] G. F. Gebhardt, G. S. Carpenter and J. F. Sherry Jr., "Creating a Market Orientation: A Longitudinal, Multifirm, Grounded Analysis of Cultural Transformation," Journal of Marketing, Vol. 70, No. 4, 2006, pp. 37-55. doi:10.1509/jmkg.70.4.37

[24] A. K. Kohli and B. J. Jaworski, "Market Orientation: The Construct, Research Propositions, and Managerial Implications," Journal of Marketing, Vol. 54, No. 2, 1990, pp. 1-18. doi: $10.2307 / 1251866$

[25] W. Wells and D. Tigert, "Activities, Interests, and Opinions," Journal of Advertising Research, Vol. 11, No.4, 1971, pp. 27-35.

[26] W. A. Kamakura and M. Wedel, "Life-Style Segmentation with Tailored Interviewing," Journal of Marketing Research, Vol. 32, No. 3, 1995, pp. 308-408.

[27] O. Kucukemiroglu, "Market Segmentation by Using Consumer Lifestyle Dimensions and Ethnocentrism: An Empirical Study," European Journal of Marketing, Vol. 33, No. 5/6, 1999, pp. 470-487. doi:10.1108/03090569910262053

[28] G. Tellis and G. J. Gaeth, "Best Value, Price-Seeking, and Price Aversion: The Impact of Information and Learning on Consumer Choices," Journal of Marketing, Vol. 54, No. 2, 1990, pp. 34-45. doi:10.2307/1251868

[29] L. B. Crosby, R. D. Vito and J. M. Pearson, "Management Your Customers' Perception of Quality," Review of Business, Vol. 24, No. 1, 2003, pp. 18-24.

[30] R. K. Teas and S. Agarwal, "The Effects of Extrinsic Product Cues on Consumers' Perceptions of Quality, Sacrifice, and Value," Academy of Marketing Science Journal, Vol. 28, No. 2, 2000, pp. 278-291. doi: $10.1177 / 0092070300282008$

[31] U. R. Orth, M. McDaniel, T. Shellhammer and K. Lopetcharat, "Promoting Brand Benefits: The Role of Consumer Psychographics and Lifestyle," Journal of Consumer Marketing, Vol. 21, No. 2, 2004, pp. 97-108. doi: $10.1108 / 07363760410525669$

[32] A. M. Thompson and P. F. Kaminski, "Psychographic and Lifestyle Antecedents of Service Quality Expectations," Journal of Services Marketing, Vol. 7, No. 4, 1993, pp. 53-61. doi:10.1108/08876049310047742

[33] D. Champion, "Marketing: The Bright Side of Gray Markets," Harvard Business Review, Vol. 76, No. 5, 1998, pp. 19-22.

[34] J. H. Huang, B. C. Y. Lee and S. H. Ho, "Consumer Attitude toward Gray Market Goods," International Marketing Review, Vol. 21, No. 6, 2004, pp. 598-614. doi: $10.1108 / 02651330410568033-$

[35] H. Li, T. Daugherty and F. Biocca, "Impact of 3-D Advertising on Product Knowledge, Brand Attitude, and Purchase Intention: The Mediating Role of Presence," Journal of Advertising, Vol. 31, No.3, 2002, pp. 43-58.

[36] C. R. Newberry, B. R. Klemz and C. Boshoff, "Managerial Implications of Predicting Purchase Behavior from Purchase Intentions: A Retail Patronage Case Study," The Journal of Services Marketing, Vol. 17, No. 6, 2003, pp. 609-619. doi:10.1108/08876040310495636 
[37] J. C. Bou, C. Camison and A. B. Escrig, "Measuring the Relationship between Firm Perceived Quality and Customer Satisfaction and Its Influence on Purchase Intentions," Total Quality Management, Vol. 12, No. 6, 2001, pp. 719-734.

[38] W. B. Dodds, K. B. Monroe and D. Grewal, "Effects of Price, Brand and Store Information on Buyers' Product Evaluations," Journal of Marketing Research, Vol. 28, No. 3, 1991, pp. 307-319. doi:10.2307/3172866

[39] C. A. Martin and A. J. Bush, "Do Role Models Influence Teenagers' Purchase Intentions and Behavior?" Journal of Consumer Marketing, Vol. 17, No. 5, 2000, pp. 441455. doi:10.1108/07363760010341081

[40] M. R. Young, W. S. DeSarbo and V. G. Morwitz, "The Stochastic Modeling of Purchase Intentions and Behavior," Management Science, Vol. 44, No. 2, 1998, pp. 188202. doi: $10.1287 / \mathrm{mnsc} .44 .2 .188$

[41] S. Todd and R. Lawson, "Lifestyle Segmentation and
Museum/Gallery Visiting Behavior," International Journal of Nonprofit and Voluntary Sector Marketing, Vol. 6, No. 3, 2001, pp. 269-277. doi:10.1002/nvsm.152

[42] R. Tsiotsou, "The Role of Perceived Product Quality and Overall Satisfaction on Purchase Intentions," International Journal of Consumer Studies, Vol. 30, No. 2, 2006, pp. 207-217. doi:10.1111/j.1470-6431.2005.00477.x

[43] D. Shawyer, N. French and A. McGann, "The Effect of Price Cues on Perceived Product Quality in a Grocery Shopping Simulation," European Journal of Marketing, Vol. 6, No. 4, 1972, pp. 217-222. doi:10.1108/EUM0000000005143

[44] M. H. Goode and L. C. Harris, "Online Behavioural Intentions: An Empirical Investigation of Antecedents and Moderators," European Journal of Marketing, Vol. 41, No. 5-6, 2007, pp. 512-536. doi: $10.1108 / 03090560710737589$ 